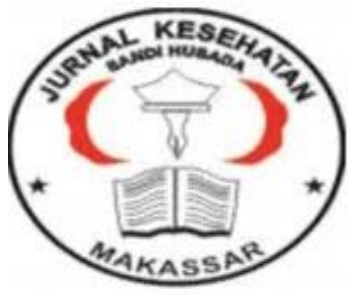

\author{
Jurnal Ilmiah Kesehatan Sandi Husada \\ hhttps://akper-sandikarsa.e-journal.id/JIKSH \\ Volume 9, Nomor 2, Desember 2020, pp 940-946 \\ p-ISSN: 2354-6093 dan e-ISSN: 2654-4563 \\ DOI: $10.35816 /$ jiskh.v10i2.437
}

Literature Review

\title{
Sindrom Operasi Punggung Gagal
}

Failed Back Surgery Syndrome

Fikri Muhammad Rifai Patongai

Fakultas Kedokteran, Universitas Lampung

\section{Artikel info}

Artikel history:

Received; Juli 2020

Revised: Agustus 2020

Accepted; September 2020

\begin{abstract}
Background; failed back surgery syndrome is low back pain that has no known cause even though it has been intervened or appears after surgical intervention aimed at relieving pain in the same location. The aim of this study is that the authors want to present the knowledge about this disease and compare the efficacy between therapies with the Traditional Review method regarding failed back surgery syndrome and its treatment. Result; Strong evidence from large randomized trials shows the superiority of spinal cord stimulation over conservative management and repeated surgery for back surgery syndrome failed to show better neuromodulation than conventional therapy. Conclusion; neuromodulation therapy modalities showed more satisfactory results than other therapies.
\end{abstract}

Absktrak.

Latar belakang; sindrom operasi punggung gagal adalah nyeri punggung bawah yang tidak diketahui penyebabnya meskipun sudah dilakukan intervensi atau muncul setelah intervensi operasi yang bertujuan untuk menghilangkan nyeri di lokasi yang sama. Tujuan dari penelitain ini adalah penulis ingin memaparkan pengetahuan tentang penyakit ini dan membandingkan efikasi antar terapi dengan metode Traditional Review terkait sindrom operasi punggung gagal dan terapinya. Hasil; bukti kuat dari uji coba acak besar menunjukkan keunggulan stimualsi sumsum tulang belakang dibanding manajemen konservatif dan operasi berulang untuk sindrom operasi punggung gagal menunjukkan neuromodulasi lebih baik dari terapi konvensional. Kesimpulan; modalitas terapi neuromodulasi menunjukkan hasil yang lebih memuaskan dibanding terapi lain.

\section{Keywords:}

Nyeri;

Punggung Gagal;

Terapi neuromodulasi;
Coresponden author: Email: fikri010899@gmail.com artikel dengan akses terbuka dibawah lisensi CC BY -4.0 


\section{Pendahuluan}

Nyeri punggung bawah atau LBP (Low Back Pain) merupakan kondisi yang umum ditemukan di praktik kedokteran, setidaknya terdapat insidensi 9,4\% diseluruh dunia, dan prevalensi $60-80 \%$ pada populasi global. Meningkatnya angka harapan hidup juga meningkatkan angka kejadian nyeri punggung bawah yang umumnya diderita pasien berumur 65 tahun keatas. Pada tahun 2007, Amerika Serikat mengalami peningkatan angka nyeri punggung bawah kronik sekitar $64 \%$ (dari 7 juta ke 12,8 juta). Umur rata-rata penderita nyeri punggung bawah kronik berkisar 48,5 - 52,2 tahun, dengan meningkatnya prevalensi nyeri punggung bawah terdapat juga peningkatan jumlah operasi untuk mengobati nyeri punggung bawah (Baber \& Erdek, 2016).

Hasil terapi jangka panjang LBP akut (Low Back Pain) cukup memuaskas, rasa nyeri cepat hilang dan disabilitas untuk bekerja hilang dalam satu bulan (Baber \& Erdek, 2016). Namun, Pasien dengan LBP kronis sedikit yang mendapat kesembuhan dan terapi lebih fokus untuk mengontrol nyeri dan meningkatkan aktivitas, seingga pasien LBP kronis kadang membutuhkan operasi. Intervensi operasi dibagi menjadi dua kategori: kondisi nyeri radikuler karena saraf terjepit atau stenosis spinal dengan atau tanpa spondylolisthesis degeneratif dan LBP non-spesifik (terdapat perubahan degeneratif pada diskus intervertebral atau sendi facet) (Chou, 2020).

Terkadang operasi tulang belakang tidak selalu memberikan kesembuhan dan hanya meredakan gejala sementara, operasi tulang belakang juga bisa menyebabkan nyeri yang memiliki nama sendiri yaitu Failed Back Surgery Syndrome. Gejala dari Failed Back Surgery Syndrome adalah nyeri punggung bawah, nyeri tumpul, mati rasa, sensasi dingin, dan paresthesia setelah operasi masing-masing adalah $94,0 \%, 71,1 \%, 69,8 \%, 43,3 \%$, dan 35,3\%. (Inoue et al., 2017). Pada tahun 2019 dilakukan penelitian terbaru terkait terapi Failed Back Surgery Syndrome menggunakan Subcutaneus Nerve Stimulation. Dari penelitian yang dilakukan, banyak sekali modalitas tatalaksana terkait Failed Back Surgery Syndrome, seperti manajemen konservatif hingga neuromodulasi. Angka kejadian dari sindrom operasi punggung gagal cukup tinggi, maka dari itu penulis ingin memaparkan pengetahuan tentang penyakit tersebut dan membandingkan efikasi tatalaksana lama dan baru terkait Failed Back Surgery Syndrome.

\section{Metode}

Proses literature review yang dilakukan pada 07 September 2020 menggunakan metode Traditional Review. Tahap pertama yang dilakukan adalah menetukan masalah yang diangkat menjadi topik dalam dalam ini penulis mengangkat tema bedah saraf dan orthopedi dan topik berupa sindrom operasi punggun gagal. Tahap kedua adalah mencari literatur, penulis mencari literatur menggunakan website kata kunci "failed back surgery syndrome", dan "failed back surgery syndrome therapy", sumber yang dipakai menggunakan kriteria PMC, free-full text, dan 10 tahun terakhir. Tahap ketiga adalah evaluasi data untuk mencari sumber data yang tepat dan sesuai kebutuhan guna mendukung penelitian. Tahap terakhir adalah analisis dan intrepetasi dari sumber-sumber yang sudah dipilih sesuai kriteria dan kontribusi.

\section{Hasil dan Pembahasan}

Failed Back Surgery syndrome (FBSS) atau Sindrom Operasi Punggung Gagal adalah nyeri punggung bawah yang tidak diketahui penyebabnya meskipun sudah dilakukan intervensi atau muncul setelah intervensi operasi yang bertujuan untuk menghilangkan nyeri di lokasi yang sama (Baber \& Erdek, 2016). FBSS memiliki banyak etiologi penyebab dan heterogenitas gejala yang ditandai di antara pasien. Meskipun efek melemahkan pada 
pasien dan prevalensi yang cukup tinggi di antara populasi yang menerima operasi punggung, hanya sedikit uji klinis yang dilakukan untuk menyelidiki pengobatan untuk FBSS (Chan \& Peng, 2011). Pasien yang mengalami FBSS memiliki gejala klinis berupa nyeri punggung bawah kronik dengan atau tanpa gejala nyeri alih dan/atau gejala radikuler. Kebanyakan dokter menggunakan istilah FBSS, tetapi istilah tersebut kurang menjelaskan karakteristik klinis secara keseluruhan, istilah Postsurgical spine syndrome lebih tepat untuk digunakan (Daniell \& Osti, 2018).

Perkiraan persentase orang dewasa yang mengalami nyeri punggung bawah bawah kronis selama masa hidup mereka berkisar dari 51\% sampai 84\% (Henschke, Kamper, \& Maher, 2015). Insiden nyeri punggung bawah bawah meningkat seiring dengan usia dan jenis kelamin wanita (Shmagel, Foley, \& Ibrahim, 2016). Seiring bertambahnya usia , angka insidensi operasi untuk nyeri punggung bawah bawah meningkat secara dramatis, jumlah fusi lumbal primer, misalnya, meningkat hingga 170\% dari tahun 1998 hingga 2008 (Baber \& Erdek, 2016). FBSS dilaporkan mempengaruhi antara 10 sampai $40 \%$ pasien setelah operasi tulang belakang, tetapi untuk memperkirakan kejadian FBSS sulit karena cakupan definisi yang luas dan etiologi yang heterogen (Inoue et al., 2017; Sebaaly, Lahoud, Rizkallah, Kreichati, \& Kharrat, 2018). Peningkatan kompleksitas dari operasi tulang belakang meningkatkan angka FBSS, tingkat kegagalan berkisar dari 30-46\% untuk fusi lumbal dan 19-25\% untuk mikrodisektomi (Chan \& Peng, 2011).

Penyebab FBSS adalah multifaktorial, termasuk preoperatif, intraoperatif, dan postoperatif. Faktor preoperatif pasien meliputi anxietas, depresi, atau gejala psikiatri lainya, obesitas, merokok, ada tidaknya jaminan kompensasi pekerja, dan/atau temuan fisik atau radiologi berupa stenosis,fibrosis, dan herniasi diskus (Clancy, Quinn, \& Wilson, 2017). Faktor psikososial memiliki pengaruh paling besar dalam terjadinya FBSS. Ditambah faktor operator atau prosedur operasi yang kurang memadai berkolerasi dengan meningkatnya resiko terjadinya FBSS (Chan \& Peng, 2011). Pasien yang memiliki Riwayat operasi tulang belakang berulang kali memiliki resiko yang lebih besar mengalami FBSS dan kemungkinan kecil menghilangkan nyeri setelah operasi (Daniell \& Osti, 2018). Faktor intraoperatif pasien dalam perkembangan FBSS termasuk operasi pada tulang belakang yang salah atau operasi pada satu tulang punggung atau vertebra sementara asal mula nyeri mencakup beberapa tingkat vertebra sehingga nyeri tidak hilang (Chan \& Peng, 2011; Daniell \& Osti, 2018). Operasi pada vertebra yang salah mungkin berkaitan dengan faktor-faktor seperti lumbarisasi, sakralisasi, atau bahkan lebih penting ketika etiologi dikaitkan dengan patologi yang tidak dapat dikaitkan. Faktor-faktor ini ambigu dalam mengidentifikasi penyebab pada pasien dengan perubahan multi-segmen. Teknik yang tidak tepat selama operasi juga dapat menyebabkan kegagalan untuk menghilangkan rasa sakit atau timbulnya nyeri baru (Daniell \& Osti, 2018).

Faktor Postoperatif pasien dapat disebabkan oleh banyak faktor. Misalnya nyeri bisa terjadi pada degenerasi lebih lanjut dari tulang belakang atau kelainan vertebra dengan onset baru, atau dapat terjadi akibat trauma atau stres dari otot yang berdekatan. Operasi tulang belakang sering kali menyebabkan perubahan biomekanik di area tersebut, yang mengakibatkan peningkatan beban dalam struktur yang berdekatan. Ini bisa mempercepat perubahan degeneratif di tulang belakang baik di atas maupun di bawah area operasi fusi, fusi vertebra lumbal ke sakrum juga fusi beberapa segmen dapat menyebabkan penyakit sendi sakroiliaka (Orhurhu et al., 2020). Perubahan degeneratif dari tulang belakang termasuk artropati sendi facet, yang dapat menyebabkan stenosis foraminalis onset baru. Perubahan pada diskus intervertebralis termasuk degenerasi diskus atau HNP (Herniated Nucleous Pulposus) onset baru atau saraf terjepit yang dapat menyebabkan stenosis sentral atau foraminal (Cho et al., 2017). Stenosis juga dapat diakibatkan atau diperburuk oleh 
adhesi epidural yang mungkin terbentuk setelah operasi. Perubahan biomekanik yang disebabkan operasi tulang belakang dapat terjadi akibat peningkatan ketegangan pada prevertebralis dan postvertebralis otot-otot yang secara langsung mengontrol gerakan tulang belakang.

Patofisiologi FBSS tidak begitu jelas dan disebabkan oleh beberapa faktor. Stenosis lateral foramina telah diidentifikasi sebagai kelainan struktural yang paling umum ditemukan pada pasien dengan FBSS. Namun, kelainan umum lainnya pada pasien FBSS termasuk degenerasi diskus yang menyakitkan, herniasi diskus, nyeri neuropatik, dan pseudoarthrosis (Orhurhu et al., 2020). Temuan patofisiologis yang terkait dengan FBSS termasuk operasi dengan indikasi fibrosis epidural, peningkatan ketidakstabilan tulang belakang karena disektomi atau laminektomi, dan redistribusi beban ke jaringan diskus yang berdekatan, sebuah fenomena yang dikenal sebagai "sindrom transisi" (Chan \& Peng, 2011).

Anamnesis yang akurat dan pemeriksaan fisik yang menyeluruh pada pasien dengan nyeri persisten setelah operasi tulang belakang bawah sangat penting untuk mendapatkan diagnosis yang benar. Karakter dan lokasi nyeri pasien harus diidentifikasi dan dibandingkan dengan nyeri prabedah, nyeri yang tidak reda setelah operasi dapat mengindikasikan operasi pada tingkat yang salah, sedangkan nyeri onset baru dapat mengindikasikan kerusakan saraf akibat pembedahan (Baber \& Erdek, 2016). Nyeri di kaki kemungkinan mengindikasikan kompresi saraf akibat stenosis, fibrosis epidural, atau herniasi diskus, sedangkan nyeri punggung bawah bawah lebih sering terjadi pada artropati sendi facet, masalah sendi sakroiliaka, atau etiologi myofascial (Chan \& Peng, 2011). Pasien harus ditanyai tentang gejala tanda bahaya yang mungkin mengindikasikan kondisi yang mengancam jiwa seperti: saddle anastesi atau inkontinensia usus dan kandung kemih yang menunjukkan sindrom cauda equina, demam, menggigil, atau penurunan berat badan yang mengindikasikan infeksi dan tanda-tanda keganasan (Chan \& Peng, 2011; Daniell \& Osti, 2018). Pasien juga harus menjalani evaluasi untuk kecemasan, depresi, dan kondisi kejiwaan lainnya karena komorbiditas yang tinggi dengan FBSS (Daniell \& Osti, 2018).

Pemeriksaan fisik untuk pasien FBSS umumnya tidak terlalu berarti untuk mengidentifikasi etiologi nyeri yang spesifik, meskipun kemungkin ditemukan beberapa temuan sugestif (Daniell \& Osti, 2018). Gejala akibat stenosis spinal biasanya diperburuk dengan ekstensi tulang belakang dan berkurang dengan fleksi, sedangkan nyeri akibat herniasi diskus dapat positif pada straight leg raise. Defisit neurologis fokal pada pasien FBSS memerlukan pengujian lebih lanjut, Penurunan kekuatan atau sensasi pada ekstremitas bawah dapat membantu mengidentifikasi akar saraf mana yang terpengaruh. Tanda Waddell dapat digunakan untuk mengevaluasi etiologi psikogenik dari nyeri punggung bawah bawah; sementara interpretasi dari tes ini masih kontroversial, tes ini mungkin berguna terutama jika ada kecurigaan akan etiologi sekunder (Chan \& Peng, 2011).

Pemeriksaan X-ray atau rongent dapat dilakukan dengan alasan simpel dan murah untuk dugaan FBSS. Pemeriksaan X-ray berguna untuk mendeteksi cacat tulang belakang dan sakroiliaka dan/atau misalignment dan lebih baik dari MRI untuk mendeteksi spondylolisthesis (Sebaaly et al., 2018). Degenerasi segmen yang berdekatan dan lordosis adalah kelainan umum yang ditemukan pada radiografi (Daniell \& Osti, 2018). Namun, pemeriksaan rongent tidak dapat mendeteksi stenosis spinal, yang merupakan temuan patologis yang paling umum pada FBSS, dan tidak dapat mengevaluasi jaringan lunak, seperti diskus intervertebralis, jaringan parut epidural atau fibrosis (Baber \& Erdek, 2016; Chan \& Peng, 2011). MRI dengan dan tanpa kontras terus menjadi modalitas pencitraan gold standard untuk FBSS karena kemampuannya yang sangat baik untuk mendeteksi kelainan jaringan lunak seperti fibrosis epidural dan herniasi diskus (Daniell \& Osti, 2018). Kontras 
diindikasikan lebih baik pada pasien dengan riwayat operasi herniasi diskus (Orhurhu et al., 2020). Pada pasien dengan implan feromagnetik, CT myelogram dapat digunakan untuk menghindari artefak implan yang terlihat pada MRI (Chan \& Peng, 2011; Hussain \& Erdek, 2014).

Tes lain dapat digunakan untuk menjelaskan etiologi FBSS dan membedakannya dari penyebab lain nyeri punggung bawah. Tingkat sedimentasi eritrosit dan C-reaktif protein (CRP) dapat digunakan untuk mengevaluasi kemungkinan infeksi, terutama pada pasien dengan gejala konstitusional atau predisposisi terhadap infeksi (Daniell \& Osti, 2018). Diagnostic nerve block dapat digunakan untuk mendiagnosis etiologi spesifik FBSS seperti artropati sendi facet (dual medial branck block), nyeri sendi sakroiliaka (lateral branch block dan injeksi intra-artikular), dan stenosis foraminal (blok epidural transforaminal dan selective single level block), dan dapat mengidentifikasi saraf spesifik yang terkait dengan gejala pasien. Jika dikombinasikan dengan steroid, prosedur diagnostik ini juga dapat meredakan terapi (Baber \& Erdek, 2016). Kepatuhan yang ketat terhadap standar penempatan jarum yang akurat, injeksi kontras, serta zat aktif yang terbatas sangat penting dalam meningkatkan sensitivitas dan spesifisitas blok ini. Prosedur diagnostik harus teliti karena sangat penting bagi pasien, dan penggunaan steroid diminimalkan atau dihindari untuk mengurangi hasil positif palsu.

Terapi untuk FBSS secara luas dibagi menjadi manajemen konservatif (terapi fisik atau pengobatan) dan agresif (intervensi atau bedah). Manajemen konservatif harus selalu menjadi pilihan pertama sebelum prosedur invasif untuk pasien tanpa indikasi untuk operasi darurat (Daniell \& Osti, 2018). Studi tentang pengobatan konservatif, khususnya untuk FBSS sulit ditemukan, dan penelitian yang ada seringkali bertentangan (Desai, Nava, Rigoard, Shah, \& Taylor, 2015). Tatalaksana farmakologis secara umum termasuk obat antiinflamasi non steroid (NSAID), opioid, antikonvulsan, dan antidepresan. NSAID adalah obat yang biasa diresepkan untuk etiologi nyeri punggung bawah lainnya dan terbukti memiliki keunggulan dibandingkan placebo (Baber \& Erdek, 2016). Meskipun opioid biasanya digunakan untuk mengobati nyeri kronis, bukti penggunaannya di FBSS umumnya lemah, dan risiko ketergantungan dan gangguan penggunaan zat yang diakibatkannya harus menjadi pertimbangan yang kuat sebelum digunakan. Dengan demikian, ini harus dianggap sebagai upaya terakhir dan hanya dilakukan dalam tatalaksana multidisiplin. Percobaan kecil menggunakan antikonvulsan seperti gabapentinoids atau antidepresan dalam terapi FBSS telah menunjukkan hasil awal yang menjanjikan, tetapi khasiat jangka panjang belum ditentukan (Amirdelfan, Webster, Poree, Sukul, \& McRoberts, 2017; Chan \& Peng, 2011; Desai et al., 2015).

Bukti kuat dengan Level II (small randomized controlled trial [RCT]) menunjukkan kemanjuran terapi fisik aktif pada pasien yang mengonsumsi gabapentinoids. (Amirdelfan, 2017) Terapi fisik harus fokus pada pengembangan toleransi, adaptasi system saraf, pengkondisian, dan latihan yang dilakukan dalam satu kesatuan di bawah arahan dokter spesialis atau ahli terapi fisik berpengalaman yang memahami penyakit, kekuatan dan keterbatasan pasien. Cognitive behavior therapy (CBT) atau terapi perilaku kognitif atau terapi psikiatri lainnya dapat memberikan hasil yang lebih baik pada pasien dengan FBSS dan dapat meningkatkan kemanjuran pengobatan intervensi untuk rasa nyeri pasien (Sparkes et al., 2010).

Terapi intervensi untuk FBSS sangat bergantung pada sub-etiologi nyeri pasien dan deformitas spesifik pada pencitraan. Jika penyakit sendi facet teridentifikasi, prosedur seperti medial branch nerve block atau ablasi frekuensi radio dapat dilakukan untuk menyembuhkan patologi. Ablasi frekuensi radio harus dilakukan dalam mode kontinu dengan jarum bor besar yang ditempatkan sejajar dengan saraf untuk memaksimalkan 
kemungkinan terjadinya interupsi oleh segmen saraf yang berdekatan, sehingga nyeri kronis dapat reda. Demikian juga, adhesiolisis telah terbukti menjadi pengobatan yang efektif untuk FBSS di mana fibrosis epidural merupakan faktor utama yang berkontribusi (Hussain \& Erdek, 2014). Secara umum, injeksi steroid epidural dapat menjadi pengobatan yang efektif untuk beberapa patologi yang menyebabkan FBSS, seperti fibrosis epidural, gangguan diskus atau herniasi, dan stenosis tulang belakang (Chan \& Peng, 2011). Namun, kualitas penelitian ini umumnya berkualitas sedang atau lemah, terdapat beberapa kontroversi mengenai seberapa efektif sebenarnya suntikan epidural (Hussain \& Erdek, 2014).

Terapi neuromodulator untuk FBSS, seperti stimulasi sumsum tulang belakang atau spinal cord stimulation (SCS), dilakukan dengan cara implantasi perangkat stimulasi untuk mengurangi rasa sakit pasien. Bukti kuat dari uji coba acak besar (RCT) menunjukkan keunggulan SCS dibanging manajemen konservatif dan operasi berulang untuk FBSS.(Chan \& Peng, 2011) Selain itu, percobaan efikasi SCS mudah dilakukan dengan akses perangkat secara perkutan sebelum implantasi permanen. Namun, stimulasi sumsum tulang belakang bukanlah obat mujarab,implantasi permanen gagal meredakan nyeri jangka panjang pada sekitar 40\% pasien (Orhurhu et al., 2020). SCS juga membutuhkan biaya yang tinggi pada saat implantasi, meskipun secara jangka panjang SCS lebih murah dibandingkan terapi lain (Chan \& Peng, 2011).

Ada juga operasi ulang dapat menjadi pilihan untuk pasien dengan patologi yang teridentifikasi dengan jelas yang dapat diobati dengan operasi. Seperti disebutkan di atas, operasi ulang umumnya berkorelasi dengan hasil yang kurang memuaskan dan morbiditas yang lebih tinggi dibandingkan dengan teknologi implan seperti SCS. Namun, kehadiran gejala tertentu, seperti gangguan usus / kandung kemih, kelemahan motorik, atau defisit saraf memerlukan intervensi bedah segera (Baber \& Erdek, 2016; Hussain \& Erdek, 2014). Sindrom Operasi Punggung Gagal telah terbukti menjadi kondisi yang sulit dialami oleh pasien dan kondisi yang menantang untuk dirawat oleh dokter. Dibandingkan dengan pasien dengan sindrom nyeri kronis lainnya, termasuk rheumatoid arthritis, osteoartritis, dan fibromyalgia, pasien FBSS telah terbukti menunjukkan skor kualitas hidup yang lebih rendah dan jumlah rasa sakit yang lebih tinggi, pengangguran, penggunaan opioid, dan kecacatan (Orhurhu et al., 2020).

Terapi tradisional stimulasi sumsum tulang belakang (SCS) telah menunjukkan keberhasilan dalam pengobatan pasien dengan FBSS yang mengalami nyeri tungkai dominan. Namun, bukti keampuhannya pada pasien dengan predominan atau nyeri punggung bawah tetap tidak meyakinkan. Maka muncul modalitas terapi baru yaitu Subcutaneous Nerve Stimulation. Penelitian terbaru yang membandingkan Subcutaneous Nerve Stimulation (SubQ) dengan OMM (Optimized Medical Management) menunjukkan terapi SubQ lebih baik secara klinis dan statistic daripada OMM (Sam S. et al., 2019). Hasil dari pengobatan tergantung dari pilihan terapi yang diambil pasien, bukti penelitian yang lebih kuat ada untuk hasil yang lebih menguntungkan pada pasien yang diobati dengan SCS (Cho et al., 2017). Peningkatan jumlah operasi revisi dikaitkan dengan kemungkinan yang semakin rendah untuk menghilangkan rasa sakit (Chou, 2020; Daniell \& Osti, 2018). Stimulasi sumsum tulang belakang sekarang menjadi pengobatan pilihan, setelah faktor psikososial diperhitungkan, dan setelah kegagalan manajemen konservatif, termasuk terapi fisik aktif, diagnostic blocks diikuti oleh modalitas terapeutik seperti yang ditunjukkan. SCS harus menjadi pilihan jika memungkinkan, dan sebelum mempertimbangkan terapi opioid jangka panjang. Selain nyeri punggung bawah yang parah, pasien dengan failed back surgery syndrome sering menderita penyakit yang mendahului. Gejala psikiatrik menjadi komorbid umum yang terjadi pada pasien FBSS dan berkorelasi dengan hasil nyeri yang lebih buruk. 
Sebuah survei terhadap pasien FBSS menemukan bahwa 67 dari 78 pasien dengan FBSS menderita depresi, dengan sebagian besar mengalami gejala depresi setelah/ditambah nyeri.(Inoue et al., 2017).

\section{Kesimpulan}

Nyeri punggung bawah atau LBP (Low Back Pain) merupakan kondisi yang umum ditemukan di praktik kedokteran, setidaknya terdapat insidensi 9,4\% diseluruh dunia, dan prevalensi $60-80 \%$ pada populasi global. Hasil terapi jangka panjang LBP akut (Low Back Pain) cukup memuaskas, tetapi LBP kronis sedikit yang mendapat kesembuhan dan terapi lebih fokus untuk mengontrol nyeri, meningkatkan aktivitas, dan kadang membutuhkan operasi. Terkadang operasi tulang belakang tidak selalu memberikan kesembuhan dan hanya meredakan gejala sementara, operasi tulang belakang juga bisa menyebabkan nyeri yang memiliki nama sendiri yaitu Failed Back Surgery Syndrome. Lalu dilakukan proses literature review yang dilakukan pada 07 September 2020 menggunakan metode Traditional Review tentang penyakit tersebut dan membandingkan efikasi tatalaksana lama dan baru terkait Failed Back Surgery Syndrome.

Failed Back Surgery syndrome (FBSS) atau Sindrom Operasi Punggung Gagal adalah nyeri punggung bawah yang tidak diketahui penyebabnya meskipun sudah dilakukan intervensi atau muncul setelah intervensi operasi yang bertujuan untuk menghilangkan nyeri di lokasi yang sama Manifestasi klinis berupa nyeri punggung bawah, mati rasa, dan paresthesia. Penyebab FBSS adalah multifaktorial, termasuk preoperatif, intraoperatif, dan postoperatif. Diagnosis ditegakkan dari anamnesis yang akurat dan pemeriksaan fisik yang menyeluruh pada pasien dengan nyeri persisten setelah operasi tulang belakang bawah sangat penting untuk mendapatkan diagnosis yang benar, dan pemeriksaan penunjang seperti pemeriksaan X-ray atau rongent dapat dilakukan dengan alasan simpel dan murah untuk dugaan FBSS. Terapi untuk FBSS secara luas dibagi menjadi manajemen konservatif (terapi fisik atau pengobatan) dan agresif (intervensi atau bedah). Prognosis atau hasil dari pengobatan tergantung dari pilihan terapi yang diambil pasien. Bukti penelitian yang lebih kuat ada untuk hasil yang lebih menguntungkan pada pasien yang diobati dengan SCS dan kesimpulnanya modalitas terapi Neuromodulasi menunjukkan hasil yang lebih memuaskan dibanding terapi lain.

\section{Daftar Rujukan}

Amirdelfan, K., Webster, L., Poree, L., Sukul, V., \& McRoberts, P. (2017). Treatment Options for Failed Back Surgery Syndrome Patients With Refractory Chronic Pain: An Evidence Based Approach. Spine, 42 Suppl 14, S41-S52.

Baber, Z., \& Erdek, M. (2016). Failed back surgery syndrome: Current perspectives. Journal of Pain Research, Volume 9, 979-987.

Chan, C., \& Peng, P. (2011). Failed back surgery syndrome. Pain Medicine (Malden, Mass.), 12(4), 577-606.

Cho, J. H., Lee, J. H., Song, K. S., Hong, J.-Y., Joo, Y.-S., Lee, D.-H., Hwang, C. J., et al. (2017). Treatment Outcomes for Patients with Failed Back Surgery. Pain Physician, 20(1), E29-E43.

Chou, R. (2020, April 23). Subacute and chronic low back pain: Surgical treatmentUpToDate. Retrieved September 11, 2020, from https://www.uptodate.com/contents/subacute-and-chronic-low-back-painsurgical-treatment 
Clancy, C., Quinn, A., \& Wilson, F. (2017). The aetiologies of Failed Back Surgery Syndrome: A systematic review. Journal of Back and Musculoskeletal Rehabilitation, 30(3), 395402.

Daniell, J. R., \& Osti, O. L. (2018). Failed Back Surgery Syndrome: A Review Article. Asian Spine Journal, 12(2), 372-379.

Desai, M. J., Nava, A., Rigoard, P., Shah, B., \& Taylor, R. S. (2015). Optimal medical, rehabilitation and behavioral management in the setting of failed back surgery syndrome. Neuro-Chirurgie, 61 Suppl 1, S66-76.

Guyer, R. D., Patterson, M., \& Ohnmeiss, D. D. (2006). Failed back surgery syndrome: Diagnostic evaluation. The Journal of the American Academy of Orthopaedic Surgeons, 14(9), 534-543.

Henschke, N., Kamper, S. J., \& Maher, C. G. (2015). The epidemiology and economic consequences of pain. Mayo Clinic Proceedings, 90(1), 139-147.

Hussain, A., \& Erdek, M. (2014). Interventional pain management for failed back surgery syndrome. Pain Practice: The Official Journal of World Institute of Pain, 14(1), 64-78.

Inoue, S., Kamiya, M., Nishihara, M., Arai, Y.-C. P., Ikemoto, T., \& Ushida, T. (2017). Prevalence, characteristics, and burden of failed back surgery syndrome: The influence of various residual symptoms on patient satisfaction and quality of life as assessed by a nationwide Internet survey in Japan. Journal of Pain Research, Volume 10, 811-823.

Orhurhu, V. J., Chu, R., \& Gill, J. (2020). Failed Back Surgery Syndrome. StatPearls. Treasure Island (FL): StatPearls Publishing. Retrieved September 7, 2020, from http://www.ncbi.nlm.nih.gov/books/NBK539777/

Sam S., E., Rod S., T., Stefaan, G., Benedicte, B., Ismail, G., C, G., J, T., et al. (2019, July). A Randomized Controlled Trial of Subcutaneous Nerve Stimulation for Back Pain Due to Failed Back Surgery Syndrome: The SubQStim Study. Neuromodulation: Journal of the International Neuromodulation Society. Neuromodulation. Retrieved September 16, 2020, from https://pubmed.ncbi.nlm.nih.gov/29704437/

Sebaaly, A., Lahoud, M.-J., Rizkallah, M., Kreichati, G., \& Kharrat, K. (2018). Etiology, Evaluation, and Treatment of Failed Back Surgery Syndrome. Asian Spine Journal, 12(3), 574-585.

Shmagel, A., Foley, R., \& Ibrahim, H. (2016). Epidemiology of chronic low back pain in US adults: National Health and Nutrition Examination Survey 2009-2010. Arthritis care \& research, 68(11), 1688-1694.

Sparkes, E., Raphael, J. H., Duarte, R. V., LeMarchand, K., Jackson, C., \& Ashford, R. L. (2010). A systematic literature review of psychological characteristics as determinants of outcome for spinal cord stimulation therapy. Pain, 150(2), 284-289. 